\title{
A boa-fé no Código Civil do Quebéc: do Geral ao Particular
}

\author{
Louise Rolland ${ }^{1}$
}

\section{SUMÁRIO}

\section{INTRODUÇÃO}

I. As definições de boa-fé
A. Definições semânticas
B. Definições teferenciais

II. A boa-fé como norma de conduta

A. A delimitação das fronteiras normativas pela moralidade juridica

B. A delimitação das fronteiras normativas pela segurança juridica

III. A boa-fé como ignorância
A. A boa-fé nos sistemas de informação do direito
B. A boa-fé nos sistemas de representação e os regimes de auto-correção

\section{CONCLUSÃO}

\section{INTRODUÇÃO}

A boa-fé encontrava-se, sob o Código Civil do Baixo Canadá, na esfera dos princípios gerais. "Costume de origem savant", "regra de julgamento", "expressão de uma consciência jurídica", o princípio geral, "colocado fora do direito, em um

\footnotetext{
${ }^{1}$ Professora adjunta da Faculdade de Direito da Universidade de Montreal, Quebec, Canadá.

${ }^{2}$ J. Carbonier, Droit Civil: Inttoduction, Paris, PUF, 1990, n 139-41.

${ }^{3}$ F Ewald, L'État-providence, Paris, Grasset, 1986, p. 485.

'M. Delmas-Marty, Pour un droit commun, Paris, Seuil, 1994, p.83.
} 
contexto de junção e como ponto de prumo, unindo as diversas partes do direito e atravessando as fronteiras que as separam"'. Visto como ideal de justiça presente "em suspensão no espírito de nosso direito" é um princípio diretor transcendente que, atingindo assim um degrau de generalidade maior do que a lei, é superior e, portanto, oponível. Visto desta forma como fonte das regras de direito existentes, lido "por dedução extensiva", ele é um princípio corretor imanente, igual à lei, chamado para preencher as lacunas e para gerar uma contraponto, e assin evitar as eventuais derivas autoritárias do direito positivo ${ }^{7}$ ao qual ele está integrado por implicação necessária. O princípio geral de boa-fé, de inspiração essencialmente moral, foi assim usado em direito civil quebequense como alicerce do dever de informação, das modalidades de execução das obrigações" dos limites ao livre exercício do direito de propriedade $^{\text {in }}$; os tribunais esclareceram que as relaçōes jurídicas se inscrevem na vida em sociedade a qual, por ser harmoniosamente ordenada, impóe implicitamente a honestidade e lealdade.

O Código Civil do Quebéc reconhece explicitamente, em suas disposições preliminares, o papel fundamental dos princípios gerais como fatores determinantes das normas legislativas: pela primeira vez, o direito positivo escrito integra, por movimento sistólico, os valores morais, sociais e políticos que agem sobre a interpretação e aplicação das regras de direito. O princípio geral da boa-fé participa assim, com os outros, da composição do contexto, do ambiente dentro do qual estão mergulhadas as relações juridicas privadas. Nele os codificadores inscrevern expressamente a reforma na marcha histórica, a marca do selo da continuidade ${ }^{11}$. Há mais no entanto; a boa-fé, por movimento desta vez diastólico, de princípio geral torna-se regra: artigos 6,7 e 1375 C. c. Q. Poder-se-ia então afirmar metaforicamente que o Código Civil do Quebér respira a boa-fé, ou pelo menos respira ao titmo da boa-fé, visto que essa "noção" encontra-se, por disposições particulares, em todos os Livros do Código ${ }^{12}$.

Se a boa-fé enraiza-se na moralidade e ética, o Código Civil do Quebéc seria então um convite expresso à moralidade: em termos puramente quantitativos, a lei

${ }^{5}$ Ibid.

"J. Carbonier, supra nota 3.

${ }^{7}$ M. Delmas-Marty, supra nota 5, p. 85 .

${ }^{3}$ Banque Nationale du Canada c. Soucisse, [1981] 2 R.C.S. 339.

${ }^{9}$ Houle c. Banque canadienne nationale, [1990] 3 R.C.S. 122.

"Air-Rinousiki Ltée c. Gagnon, [1952] C.S. 149.

"Se certo se vê nela uma ruptura, nós acreditamos que ela repousa mais sobre a marca escrita que sobre a substância.

${ }^{12}$ A boa-fé é explicitamente mencionada por 93 disposiçōes (das quais 62 são novas). Seis menções no Livto das Pessoas, 12 no Livro da Família, seis no Livro das Sucessões, 15 no Livro dos Bens, 45 no Livro das Obrigaçōes, uma ro Livro das Prioridades e Hipotecas, três no Livro da Prova, duas no Livro da Prescrição e três no Livro da Publicidade dos Direitos. 
nova seria duas vezes mais "moral" que a antiga. Embora o Código Civil do Baixo Canadá não fosse indiferente à boa fé ${ }^{13}$, os juristas the dedicaram pouca atenção. Por que a boa-fé suscita agora tanto interesse, tanta interrogação e mesmo angústia na comunidade jurídica? É o crescimento das regras? É a integração dos princípios gerais ao direito positivo? Ou ainda, é a positivação das regras e seus caracteres imperativos? Se a boa-fé perturba, é menos por sua "moralidade" - o que se diria contra a virtude, contra o espirito de justiça? - que por oposição que se acredita entre suas exigências e a previsibilidade, a segurança das relações jurídicas, e mesmo a liberdade dos sujeitos de direito. $O$ antagonismo assim colocado, este conflito de valores chama o julgamento essencial a sua resolução, um julgamento de valores do qual se dizem voluntátios quem é arbitrário, emotivo, irracional. Eis o nó da inquietude, o estado de tensão, a insegurança.

Ora esses dois valores estão não somente no coração do Código Civil do Quebéc, mas ainda estão eles sustentados pela boa-fé. Nós destacaremos todas as disposições que fazem menção expressa à boa-fé - disposições gerais e disposições particulares - para tentar identificar quais são as funções que lhes atribuímos ${ }^{14}$. Segue a análise das de finições que se dá a este conceito (sç̧̃̃o I), a boa-fé impõe-se como código moral (seção II) ou se interpõe como trava da segurança (seção III). Além disto, no entanto, esta energia dinâmica se conjuga em investigação da justiça.

\section{As definições da Boa-fé}

A codificação de um princípio geral em regras gerais positivas e, da mesmo forma, em tegras particulares exige a coerência interna global que não pode ser alcançada sem o preço de um esforço de sistematização; esforço ao qual os juristas têm até agora escapado a respeito da boa-fé, em proveito de uma coesão setorial de cunho muito mais pragmático. Normalmente um conceito único, em um mesmo texto e um mesmo sistema, deveria seguir a mesma trama, a mesma trajetória, responder pela mesma definição, articular-se em características parecidas e condições semelhantes.

\footnotetext{
${ }^{13}$ Nós encontramos nele mais ou menos 64 referências, das quais 31 foram repetidas pela lei nova.

${ }^{14}$ Nossa análise concentra-se na estrutura do Código Civil do Quebéc, em sua dinâmica interna expressa por suas marcas textuais: ela näo comporta nem um estudo tnatizado de cada regime, nem um estudo exaustivo do conceito da boa-fé e de suas aplicações em direito civil quebequense.
} 


\section{A. Definições Semânticas}

O Código cinil do Quebec não oferece qualquer definição semântica ${ }^{15}$ (legal ou literal) da boa-fé. Em caso de silêncio da lei, a regra de interpretação reenvia ao senso comum. Etimologicamente, a fides latina comportava muitas acepções: a crença, o empenho solene ligado ao juramento (a fé jurada à base do consensualismo); a confiança e mais precisamente a solvabilidade; a proteção, a assistência, o apoio, a autoridade, a autenticidade, a prova. Quanto à bona fides (ou mala fides), ela fazia chamar a lealdade, a fidelidade, a honestidade, a retidão, a verdade, e mesmo a equidade quando associada ao juiz (fides judicis). Personificada, a Fides era una deusa. As definições contemporâneas apegam-se essencialmente às mesmas acepçôes, a mesma polissenia. A história lexicográfica inscreve-se na continuidade semântica, em uma variedade que não coloca obstáculos ao problema de sua definição jurídica.

\section{B. Definições Referenciais}

$\mathrm{Na}$ falta de definição semântica, nós podemos tirar de certas disposições gerais do Código Civil algumas definições referenciais ${ }^{16} \mathrm{da}$ boa-fé,

O artigo 932 C.c. $Q^{17}$ é a disposição normativa que adota mais claramente una forma definitiva. A boa-fé será então uma crença de início justificada que poderá ao final revelat-se errônea: em matéria de posse, é de boa-fé aquele que se crê titular do direito que exerce. Crença na conexão do gozo de um direito e de seu exercício, conexão entre o direito - visto como código socialmente estabelecido - e os fatos. $\mathrm{O}$ erro traz, se for o caso, sobre o gozo do direito e, nesta matéria, a boa-fé faz chamado a um estado de espírito baseado no conhecimento (ou na ignorância), alardeando assim seu perfil pacifico ${ }^{18}$.

Em outras palavras, no exercício dos direitos ou a boa-fé assume um papel ativo": ela governa a conduta das partes que se obrigam, segundo os termos do

${ }^{15}$ Una definif̧ầo semântica é fornecida pela análise do sentido de um termo no mejo de paráfrases sinônimas. Se a definição do dicionário interessa-se em propor todos os sentidos da língua - sistema construído - dá desse termo, a defniçăo do direito - sistema construido tem por função selecionar, por exclusão, un dos predicados definidores.

${ }^{16}$ A definição referencial é menos uma questão de sentido que de aplicaçào do sinal lingüístico aos objetivos extra-linguísticos aos quais reenvia esse sinal en um contexto dado, aqui nomativo.

"Art. 932. O possuidor é de boaffé se, no inicio da posse, ele é juscificado de se acreditat titular do direito real que ele exerce. Sua boa-fé cessa do dia onde a falta de título ou os vicios de sua posse ou de seu tículo são denunciado por um procedimento civil.

"Menciona-se então a boa-fé subjetiva: B. Lerebvre, "La bonne foi dans la formation du contrat", (1992) 37 R. D. McGill 1053, p. 1055.

"Menciona-se então a boa-fé objectva: ibid, p. 1056. 
artigo 1375 C.c.Q ${ }^{20}$; ou ela impõe as exigências ao exercício regular de un direito (civil) segundo o artigo 6 C.c.Q. ${ }^{21}$ Qualquer que seja então a apelação - norma de conduta, dever geral, obrigação legal ou obrigação contratual implícita - toda falha, toda violação constituirá uma falta. Falta intencional - "em vista de prejudicar outrem" ${ }^{22}$ - ou falta não intencional - "de uma maneira excessiva e desarazoada" ${ }^{23}$-, falta por ação ou onissão, falta pesada, leve e mesmo levissima ${ }^{24}$.

En alguma ações (ações de inoponibilidade) ${ }^{25}$, a boa-fé, como a fídes latina, é implicitamente definida a contrario (solvábilidade), podendo pesar uma presunção de intenção fraudulenta sobre o devedor tornado insolvente pelo contrato ${ }^{26}$.

As duas primeiras acepções dominam o nosso direito civil. Conhecimentoignorância ou dever-falta, a boa ou má fé é, em todo caso, um fator de regulamentação tanto do estado do espírito, quanto das ações do sujeito de direito. A boa-fé é considerada como baliza de normalidade na vida em sociedade, no que concerne o justo gozo e o justo exercício dos direitos. Vista como "normalidade", a boa-fé presume-se sempre ${ }^{27}$ : nosso direito dá assim uma imagem mais "rousseauista", que "hobbesiana" de seus sujeitos, é o triunfo de Émile sobre o Leviatã, do racionalssmo romântico sobre o racionalismo empirico.

20. Art. 1375. A boa-fé deve governar a conduta das partes, tanto no momento do nascimento da obrigação quanto àquele de sua execução ou de sua extinçăo.

${ }^{21}$ Art. 6. Toda pessoa deve exercer seus direitos (civis) segundo as exigências da boa-fé.

${ }^{22}$ Axt. 7. Nenhum direito pode ser exercido com vistas a prejudicar outrem ou de uma maneita excessiva e desarazoada, indo assim ao encontro das exigências da boa-fé.

${ }^{23}$ Art. 7 C.c.Q; art. 1437 C.c.Q. A cláusula abusiva de um contrato de consumo ou de adesão é nula ou a obrigação que resulta dele, redusivel. É abusiva toda cláusula que prejudique o consumidor ou o aderente de uma maneira excessiva e desarazoada, indo assim ao encontro das exigências da boa-fé; é abusiva, notadamente, a cláusula que afasta as obrigações essenciais que resultam das regras insperativas ou habitualmente do contrato desnaturando-o.

24 Art. 2545. A formação do contrato de seguro marítimo necessita a mais absoluta boa-fé. Se esta não é observada por uma das partes, a outta pode requere a nulidade do contrato. Ver $C$. Dubreuil, "L.'assurance: um contrat de bonne foi à l'étape de la formation et de l'exécution", (1.992) 37 R. D. McGill 1087.

${ }^{25}$ Art. 1631 e segs. C.c.Q.

${ }^{26}$ Art. 1632. Um contrato a útulo oneroso ou um paganento feito en execução de um determinado contrato é reputado feito com intençã̃o de fraudar se o co-contratante ou o credor conhecia a insolvabilidade do devedor ou os feitos que este, por esta ação, exprimia ou tentava exprimir-se insolvente. Art. 1633. Um contrato a título gratuito ou ura pagamento feito em execução de um determinado contrato é reputado feito com a intenção de fraudar, mesmo se o contratante ou o credor ignoravam esses feitos, sendo quando o devedor é insolvente ou torna-se no momento onde contrato é concluído ou o pagamento efetuado.

27 Art. 2805 C.c.Q; a boa-fé presume wse sempre: de maneira geral até a prova em contrátio (art.2847 C.c.Q.), em matéria de posse até a denúncia judiciária (art.932 C.c.Q.), em matéria de casamento até a declaraçäo judiciária que pode acompanhat o julgamento de nulidade (art. 387 C.c.Q.). A boa-fé presume-se sempre, a menos que a lei năo exija expressămente sua prova ou, nós adicionaríamos, não exclua a sua prova (art. 1632-1633 C.c.Q., supra nota 27). 
O conceito de boa-fé é, então, polissêmico, proteiforme $e^{28}$. Como essas definições dominantes, tiradas de dispositivos gerais do Código civil do Québec, repercutem-se nos dispositivos particulares? Quais são então as funções que lhes designamos? Quais são os valores protegidos?

\section{A boa-fé como norma de conduta}

As disposições particulares ou especializadas desenham, precisando-nas de maneira referencial, a trajetória do código moral imposto pelas disposições gerais. Imposição de deveres e obrigações, repressão ao abuso, harmonização de interesses particulares e coletivos.

A. A delimitação das fronteiras normativas pela moralidade jurídica

O direito impõe nominalmente obrigações de honestidade e de lealdade aos administradores de pessoas jurídicas ${ }^{29}$, aos administradores de bens de terceiros, ${ }^{30}$ aos mandatários ${ }^{31}$ e aos fiduciários ${ }^{32}$. O Código civil vem igualmente consagrar a obrigação (dever) de lealdade à qual estão vinculados os assalariados en relação ao seu empregador ${ }^{33}$.

Os deveres são, portanto, impostos e, como corolário, os abusos reprimidos. $\mathrm{O}$ artigo 7 do C.c.Q. condena de maneira getal o abuso de direito, condenação que desenvolve suas raizes em outras áreas: restrições, certamente, do direito de propriedade, decadência do usufruto, ${ }^{34}$ perda da "inunidade" das pessoas jurídicas, ${ }^{35}$ vício do consentimento quando há coação ou temor, ${ }^{36}$ defeito de eqüidade no exercício dos direitos contratuais. ${ }^{37} \mathrm{~A}$ má fé aniquila os privilégios normalmente em harmonia com os direitos: isto é, o sistema jurídico se fecha, recusando-se a suportar o desvio que se faz de suas próprias regras.

Se os sujeitos não devem abusar de seus direitos, eles não podem tampouco abusar de sua liberdade, por exemplo, enganando os outros. A traição, o dolo (inclusive

\footnotetext{
${ }^{28}$ B. Lefebvre, "La bonne foi: notion protéiforme".

${ }^{29}$ Art. 322 C.c.Q; art. 329 C.c.Q.: o tribunal poderia mesmo proibir o exercício da função de administrador por uma pessoa julgada desonesta; art. 327 C.c.Q: o falido é inábil para ser administrador, o que apela a outra acepção da boa-fé, vista como solvabilidade.

30 Art. 1309 C.c.Q.

3 Art. 2138 C.c.Q.

${ }^{32}$ Art. 1290 C.c.Q.

${ }^{33}$ Art. 2088 C.c.Q.: esta disposição de direito novo codifica o princípio estabelecido pela Corte suprema, embasada na boa-fé, no arrêt Banque de Montreal c. Kuet Leong Ng, [1989] 2 R.C.S. 429.

${ }^{34}$ Art. 1168 C.c.Q.

${ }^{35}$ art. 317 C.c.Q.

36 Art. 1403 C.c.Q.

${ }^{37}$ Art. 1434 C.c.Q.
} 
por silêncio ou reticência), as falsas declarações ou as declarações incompletas são fortemente punidas pelo direito. $O$ dolo, fonte de erro, vício do consentimento, faz com que seu autor perca certas vantagens (ou todas as vantagens) de um contrato 38 ou de uma instituição jurídica, como o casamento. ${ }^{39} \mathrm{Não}$ enganar os outros e não abusar dos outros, fraudando a lei ou buscando egoisticamente seu próprio beneficio.

A violação de uma disposição de ordem pública, quando há má fé pode levar a uma condenação por danos (e interesses) punitivos: assin é para o locador de um alojamento que não respeita as regras de reintegração de posse ou de evicção. ${ }^{4(1)}$ No capítulo da prova, a boa ou a má fé permite distanciar as regtas gerais de aceitação em beneficio de exceções na justa busca da verdade: divisão da confissão quando a parte contestada é contradita pelos indícios de má fé $e^{41}$ e a fastamento da regra da melhor prova quando se tornou, com a completa boa-fé, impossivel de produzi-la. ${ }^{42}$

Fonte da harmonia social, a boa-fé supõe a cooperação, única fortaleza contra os efeitos suspeitos dos inevitáveis conflitos de interesse dentro da coletividade. A busca dos interesses individuais deve ceder em toda organizaçăo comunitária. O segurador pode recusar-se a indenizar mesmo o comprador de boa-fé, ${ }^{43}$ pela aplicação do princípio da mutualidade. No mesmo espírito, o direito retira o benefício da sucessão ao herdeiro que ocultou, alterou ou destruiu de má fé o testamento do de cujus prejudicando assim os outros legatários; ${ }^{44}$ o credor hipotecátio que exige a renúncia do imóvel pode ser levado a fornecer uma garantia quando sua boa-fé é posta em dúvida, ou seja, quando sua administração puder prejudicar os interesses do devedor e, através disso, os dos outros credores; ${ }^{45}$ numa multipropriedade ou co-ptopriedade, para conservar o caráter colegial do exercício do poder de decisão, o direito fixa a proporção dos votos atribuídos ao promotor na medida da sua boa-fé, ${ }^{40}$

A boa-fé intervém, como dever positivo, em todos os casos onde as relações jurídicas são ameaçadas de desequilíbrio: a disposição legislariva desse conceito age como contrapeso dos excessos potenciais - abuso de direito e de liberdade - num sistema que busca a igualdade efetiva e a justiça (material). Esta bela coerência entre as disposições gerais e as disposições particulares rompe-se, este "trem" de moral positiva descarrilha em um ponto preciso de ruptura: a lesão.

\footnotetext{
${ }^{33}$ Art. 1401 - 1407 C.c.Q.; exigências reforçadas em matéria de seguros: art. 2408 à 2313 - 2417 $-2420-2423-2424-2434-2466-2472-2545$ a 2552 C.c.Q.

39 O esposo que se tornou cuipado por dolo no contrato de casamento (art. 365 C.c.Q.) setá declarado será declarado de má fé (art. 387 C.c.Q) e perderá os beneficios do casamento putativo (art. 382 e s. C.c.Q.).

${ }^{40}$ Art. 1968 C.c.Q.

${ }^{41}$ Art. 2853 C.c.Q.

${ }^{42}$ Art. 2860 C.c.Q.

43 Art. 2411 C.c.Q.

${ }_{44}$ Art.621 C.c.Q.

${ }^{45}$ Art. 2766 C.c.Q.

${ }^{46}$ Art. 1093 C.c.Q.
} 


\section{B. A delimitação das fronteiras normativas pela segurança jurídica}

Alérgico ao dolo, aos conflitos de interesse, aos objetivos puramente egoístas, o direito deveria também sê-lo à lesão: a boa-fé não saberia sentar-se à mesa da exploração e o direito deveria nesse sentido oferecer uma panacéia às vítimas. Ao mesmo remédio universal, preferiu-se a dosagem com base na escala força-fraqueza. Remédio forte para os incapazes ${ }^{47} \mathrm{e}$ os consumidores protegidos fora do código, ${ }^{48}$ o que põe em perigo toda tentativa de categorização; remédio monovalente e pontual para os aderentes e consumidores protegidos no código, ${ }^{49}$ dos quais a administração repousa sobre a qualificação dos contratos; remédio homeopático para os outros..$^{50}$ Contudo, a definição dada pela primeira alínea do primeiro artigo 1406 do C.c.Q. não deixa dúvidas: ele formula a adequação perfeita entre a lesão e a má-fé, isto é, a exploração de uma parte pela outra. Na medida em que a lesão entre maiores capazes não é de aplicação geral, como falar ainda de moralidade? Na medida en que as cláusulas abusivas de um contrato concluído de mútuo acordo (paritátios ou nãode-adesão) não são submetidas à revisão e à sanção, como falar ainda de justiça? A boa-fé não é mais, portanto, o fio condutor anunciado e garantido pelo direito, mas um desejo legislativo cuja realização é deixada à boa ou má "vontade" de cada um. O tratamento dado à lesão pelo Código civil provoca o declínio do dever geral de boafé em beneficio da responsabilidade individual e da segurança - estabilidade previsibilidade das relações jurídicas. O conflito de valores é patente e as escolhas legislativas provocam uma onda de choquc, e atingem plenamente a estrutura mesma do edifício.

Podemos preencher esta falha estrutural? Como? Os tribunais poderiam sem dúvida fazề-lo, mas pontualmente, por interpretação e concretização. Uma interptetação generosa do artigo 1379 C.c.Q.- - disposição definidora dos contratos de adesão - permitiria reduzir o campo dos contratos paritários (ou não por adesão), definindo-os $\mathrm{cm}$ termos residuais: este exercício modificaria enormemente a teoria geral dos contratos e, como conseqüência, o direito civil. Na mesma ordem, um alargamento dos casos de aplicação visados pelo artigo 1405 C.c.Q. daria acesso à revisão judiciária dos contratos lesionários: todas as disposições que supõem, mesmo incidentemente, desproporção e exploração poderiam ser interpretadas como casos expressamente previstos pela lei..$^{51}$ Nesse último caso, a busca por coerência contradiz

${ }^{47}$ Art. $1405-1406$ al. 2 e $163-173-287-294$ C.c.Q.

4h Lei sobre a proteção do consumidor, L.R.Q. c. P-40. 1, art. 8-9, tais como interpretados em Garear Auto Inc. c. Banque canadienne impériale de commerce, [1989] R.J.Q. 1091 (C.A.) e Banque de Montreal c. Spooner, [1994] R.J.Q. 1388 (C.S.).

${ }^{49}$ Art. 1437 C.c.Q.

${ }^{50}$ Art. $1405-1406$ al. 1 e $424-472-2332$ C.c.Q.

51 Pensemos, por exemplo, na exploraçăo do estado de necessidade previsto pelo artigo 1404 C.c.Q. 
de maneira violenta a intenção legislativa. ${ }^{52}$ Poder-semia por outro lado conceder um conteúdo positivo autônomo e intangivel aos deveres gerais da boa-fé dos artigos 6 e 1375 C.c.Q., o que suscita o problema da sanção: se as exigencias da boa-fé são consideradas como regras de conduta em sociedade, toda violação é um delito que exige reparação em caso de preconceito e aplicação do regime da responsabilidade extracontrarual, ${ }^{53}$ expulsando assim a lesão da teoria dos vícios do consentimento e das sanções a ela combinadas, a saber, os remédios, entre os quais a nulidade, previstos nos artigos 1407 e 1408 C.c.Q. Todo esforço de coerência, constata-se, convida à tortura das regras: a boa-fé e o tratamento legislativo da lesão provocam uma colisão Erontal dos valores presentes.

A boa-fé normativa, ativa, editada pelas disposições gerais encontra na maioria das vezes apoio nas disposições particulares: a boa ou má-fé é a chave de abertura ou fechamento do sistema que reage à moralidade das relaçōes jurídicas, salvo em matéria de lesão entre maiores capazes, onde a estabilidade das relações juúdicas parece dominar. Na maior parte dos casos, a honestidade, a lealdade, a retidão são bases de relações sociais harmoniosas e igualitárias. Mas não é esta a aceitação da boa-fé mais utilizada no Código cinil do Québer: a maioria das disposiçōes particulares põe o acento sobre o conhecimento ou a ignorância, casamento duplo ignorância/boa fé e conhecimento/ má fé que obriga o direito a pronunciar irrevogavelmente o divórcio do casal: aparência/ realidade.

\section{A Boa-Fé como Ignorância}

É de boa-fé a pesson que ignora a realidade, na maioria dos casos, ignorância da realidade jurídica: a existência de um direito, a identidade de seu verdadeiro titułar, a organização juridica de um grupo de pessoas. A boa-fé "ignorância" agirá como um fixador de uma realidade jurídica virtual quando o direito acaba por ser impotente en ordenar perfeitamente as relações sociais: falhas desses sistemas de informação (na parte A), cisões autorizadas de direitos e de poderes, bem como sanções e remédios retroativos (na parte $\mathrm{B}$ ).

\section{A. A Boa-Fé nos Sistemas de Informação do Direito}

Na medida em que a boa-fé se valora em funçăo do grau de conbecimento, devemos nos perguntar quais são os meios de informação utilizados. O Código Civil do Québec os separa em três grupos: a publicidade, a posse e a divulgação.

${ }^{22}$ Comentários do Ministro da Justiça, t. 1, Québec, Publicações do Québec, 1993 à página 853.

${ }^{53}$ Art. 1457 C.c.Q. 
A publicidade dos direitos é um sistema formal estabelecido para assegurar a confiabilidade das informações, a segurança das relações jurídicas. Sistema fortemente organizado e fortemente integrado, é a lei que prescreve ou autoriza a publicidade de um direito. ${ }^{54}$ Quando essa formalidade é imposta, ela exclui toda outta forma de transmissão da informação e o conhecimento adquirido não supre a falta de publicação $0^{55}$ : desde então a boa ou a má fé indifetem em un sistema fechado, tendido "moralmente cego" ${ }^{\prime \prime 56}$. Além disso, acerca de um direito publicado é suposto existir e ser conhecido. ${ }^{57}$ Ainda, a publicidade criada, por via de presunção irrefragável, os efeitos de uma prescrição aquisitiva de pleno direito que escapa às regras da posse útil. ${ }^{58}$ Mas o que acontece em caso de ineficácia? O conceito de boa-fé retoma então suas linhas de nobreza: os terceiros que confiaram nas inscrições errôneas sobre um imóvel registrado serão protegidos, na medida de sua boa-fé e na medida da publicação de seu próprio direito. ${ }^{59} \mathrm{O}$ sistema em qualquer forma se autocorrige. Essa regta getal encontra aplicações particulares a respeito dos eventos que viriam modificar a inscrição inicial e prejudicar assim a confiança das informações: registro de um julgamento ${ }^{60}$ ou da erradiação de una erradiação feita sem direito. ${ }^{61}$ Já assistimos ao triunfo das aparências sobre a realidade jurídica, com a boa-fé como referência, em nome da estabilidade e da segurança das relações juridicas.

Por outro lado, acontece que a publicidade separa a boa-fé para se justificar: o formalismo retoma toda sua energia em caso de transferencias sucessivas de um direito real sobre um imóvel. Tạl transferência se submete à publicidade ${ }^{62} \mathrm{e} o$ direito será adquirido por aquele que primeiro o tiver publicado. ${ }^{63} \mathrm{~A}$ aplicação estrita dessas regras pode ter um efeito perverso e conceder todos os beneficios jurídicos aos mais desonestos. Em duas vendas sucessivas, por exemplo, o vendedor é de má-fé, no sentido normativo do termo, en vendendo pela segunda vez aquilo que não mais lhe pertence. ${ }^{64}$ : aplicando as regras da publicidade, os dois adquirentes estariam de boa-fé ,pois, no momento da venda nenhuma inscrição aparecia no registro, senão aquela do seu autor. Por que preferir o segundo adquirente na medida en que o

\footnotetext{
${ }^{34}$ Art. 2938 C.c.Q.

${ }^{5}$ Art. 2963 C.c.Q.

${ }^{56}$ J. Carbonnier, Droit Civil, t. 3, Paris, PUF, 1992, au no 115.

57 Prestrnção simples da existência do direito publicado (art. 2944 al. 1 C.c.Q.); presunção simples de conhecimento do direito inscrito sobre o registro de direitos reais e pessoais móveis ou sobre o registro fundamental a respeito de um intransferivel não registrado, mas presunção absoluta a respeito de um intransferivel registrado (art. 2943 C.c.Q.).

58 Art. 2944 al. 2 C.c.Q.

${ }^{59}$ Art. 2962 C.c.Q

Art. 3064 C.c.Q.

${ }^{6 t}$ Art. 3075 C.c.Q.

62 Art. 1455 C.c.Q.

${ }^{63}$ Art. 2946 C.c.Q.

6it "Nemo dat quad non habet".
} 
primeiro haveria inscrito seu direito? Para punir o primeiro por sua falta de diligência, pelo efeito do consensualismo, regra gerai nessa matéria ${ }^{65}$, se seria o único proprietário verdadeiro? $\mathrm{Na}$ medida em que o segundo ignorava a primeira transferência, essa poderia ser uma solução justa. Mas na medida em que ele agia com conhecimento de causa, que ele estava de má-fé, porque the deixar o beneficio do contrato? Para proteger eventuais terceiros adquirentes de boa-fé, é dizer, que confiariam no registro? Certamente, mas ainda deve-se permitir que thes deixem entrar em cena. ${ }^{66}$ Esse formalismo põe em perigo dois princípios caros a nosso sistema jurídico, o consensualismo e a boa-fé. Nós estamos longe dos deveres de honestidade, de lealdade, de cooperação que se encontram aqui obstruídos completamente em favor da segurança das relações jurídicas. Em um direito que carece de moralidade e com uma preocupação com a interpenetração das duas acepções dominantes da boa-fé, não teria lugar, para flexibilizar, por via legislativa ou judiciária, a regta do artigo 2963 do C.c.Q.? Os tribunais franceses não hesitaram em fazê-lo. ${ }^{67}$

Outro modo de informação acolhido pelo direito, modo fático: a posse. $O$ controle material de um bem conforta seu controle jutídico. Na ausência de conexidade, no entanto, os fatos podem prevalecer ao dircito. A posse tem um efeito probatório: do possuidor se presume sua titularidade em relação ao direito que exerce ${ }^{68}$. Tal exercício carrega consigo sua efetividade pelo efeito aquisitivo da posse $\mathrm{c}^{69}$. Poder-se-ia ter tentado justificar essa instituição pela utilidade social e econômica dos bens ${ }^{70}$ : nós cremos que se trata prioritariamente da segurança de títulos. Nós sabemos que no direito do Québec, mesmo em matéria mobiliária, a posse não vale como título de aquisição uma vez que, contrariamente ao direito francês, ${ }^{71}$ um prazo de usucapião é fixado: dez anos como regra geral ${ }^{72}$ mas prazo diminuido a três anos pelos possuidores de boa-fé de um bem móvel..$^{73} \mathrm{Tem}$-se o costume de afirmar que a boa ou a má fé são indiferentes à prescrição aquisitiva salvo esse último papel redutor: isso seria esquecer a dupla acepção da boa-fé. Se a boa-fé como ignorância ${ }^{74}$ não se

${ }^{65}$ Art. 1453 C.c.Q.

${ }_{66}^{6}$ J. Pineau, D. Burman e S. Gaudet, Théorie des obligations, 3a edição, Montréal, Thémis, 1996, Pp. 361-362.

(7) Cass. Req., 7 de dezembro 1925, D.P. 1926.1.185; Cass. Civ, 10 de maio de 1949, D.1949 Jur.277; Cass. Civ, 24 de abril de 1950, D.1950.jur.499); acontece que o primeiro adquirente é preferido nesmo em ausência de fraude, sob a prova do conhecimento adquirido do segundo adquirente da existência do primeiro contrato (Cass. Civ. 3a, 22 março de 1968, D.1968.jur.412; Cass. Civ. 3a, 30 de janeiro de 1974, D.1975.Jur.427, J.C.R 1975.11.18001.

${ }^{64}$ Art. 928 C.C.Q.

Art. 930 e 2910 C.c.Q.

${ }^{70}$ Para produzir seus efeitos a posse deve ser útil (art. $922-2914-2920$ C.c.Q.).

7 Art. 2279 C.e.f.r.

72 Art. 2917 C.c.Q.

${ }^{73}$ Art. 2919 C.c.Q.

${ }^{74}$ Art. 932 C.c.Q. 
trata que do prazo e de matérias imobiliárias, ${ }^{75}$ a boa-fé normativa se impõe uma vez que os ladrões, receptadores e fraudadores não podem usucapir. ${ }^{76}$ A prescrição aquisitiva permite clarificar a realidade jurídica pelo reconhecimento das aparências, clarificação mais rápida na medida da boa-fé. ${ }^{7} \mathrm{O}$ verdadeiro titular pode, nos prazos, reivindicar seu bem contra o possuidor, salvo em caso de transferências sucessivas de um direito real sobre um mesmo bem móvel. Nós poderianos retomar o raciocínio tido em matéria imobiliária: esse ofusca menos uma vez que a boa-fé do segundo adquirente é aqui levado em conta. ${ }^{78}$ A posse e a boa-fé são, então, como cinento, cimento de aquisição que dá à transferência do bem de outrem o efeito de uma prescrição aquisitiva "instantânea".

E a questão da segurança das telações jutidicas em caso de violação? $O$ beneficio do contrato é então acordado ao segundo contratante que, se de má fé, não será tutelado que à reparação do prejúżo sofrido pelo beneficiário da promessa. ${ }^{79}$ Fragilidade das promessas na qual a boa-fé de um é posta no ancoradouro em benefício da má-fé dos outros: fenômeno de aceleração da circulação jurídica que privilegia o titno da economia em detrimento da moralidade do direito. Argüi-se que o voluntarismo na formação dos contratos. Seja, no entanto, em matéria de venda, a posse atual do beneficiário valha título ${ }^{81}$ e a execução em natureza de uma promessa de contratar pode ser forçada. ${ }^{81}$

Prescrição, prova, publicidade fática, a posse permite às aparências suplantar a realidade jurídica. Pode-se paralelamente justificar a proteção do portador de boa-fé mesmo quando o título foi posto em circulação contra a vontade do devedor. ${ }^{82} \mathrm{Ou}$ ainda o efeito liberatório do paganzento feito de boa-fé ao credor aparente. ${ }^{83}$ A posse do título, ou o estado de credor ${ }^{84}$, aliada à boa-fé, fazem o direito. A ignoxância justifica o erro, o direiro oculta sua própria realidade a fim de concluir a relação jurídica e assegurar a segurança das relações.

${ }^{75}$ A redução do prazo gexal de prescrição aquisituva a dez anos motivou o legislador a abandonar, em matéria imobiliária, o prazo diminuido para o possuidor de boa-fé (art. 2215 C.c.B.C.).

${ }^{76}$ Art. 927 C.c.Q.

7 A boa-fé tinha igualmente para efeito de reduzir a dez anos a prescrição aquisitiva normalmente de trinta anos dos imóveis (art. 2251 C.c.B.C.); o Código Civil do Québec fixa em dez anos a prescrição dos imóveis sem menção à boa-fé (art. 2917 C.c.Q.).

${ }^{78}$ Art. 1454 C.c.Q.

${ }^{79}$ Art. 1397 C.c.Q.

Bip Art. 1710 C.c.Q.

${ }^{81}$ Art. 1712 C.c.Q.

82 Art. 1649 C.c.Q.

${ }^{83}$ Art. $1559-1643$ C.c.Q.

${ }^{8 *}$ H. Mazeaud e al, Leçons de droit civil, t.2, vol, 1, $8^{\mathrm{a}}$ éd., Paris, Montchrestien, 1991 au no 833; 3. Pineau, D. Burman e S. Gaudet, supra, nota 65 p. 482. 
Além da publicidade e da posse, a informação jurídica circula pela divulgação, forçada ou espontânea. Assim, o direito obriga certas pessoas a declarar sua organização interna para poder se beneficiar completamente do regime escolhido por elas. Certas sociedades - sociedades em nome coletivo e em comandita - tinham que declarar sua existência social e seu nome; ${ }^{85}$ essa declaração faz prova de seu conteúdo señ que os associados possam o contradizer. ${ }^{86}$ Confrabilidade do sistema de informação para os terceiros. Proteção ao menos mais importante que o defeito de declatar seu estaturo ou seu defeito de dispor sua forma juridica ${ }^{87}$ pode impor aos associados uma responsabilidade pessoal mais importante - aquelas da sociedade em participação ${ }^{88}$ em relação aos terceiros de boa-fé, que ignoravam realmente seu verdadeiro estatuto. De modo geral, a divulgação traz consigo o beneficio do regime; por outro lado, a ausência de divulgação destrói o tegime, a realidade juridica inoponível aos terceiros de boa-fé. No mesmo sentido, uma divulgação tardia não porá em perigo os atos jurídicos já completados: en matéria de seguro de pessoas, o pagamento feito de boa-fé pelo segurado ao último beneficiário designado, conhecido dele, é liberatório, ${ }^{89}$ o é, igualmente, en seguro de bens, o pagamento feito de boa-fé antes da denunciação dos credores prioritários ou hipotecários. ${ }^{\text {9ti }}$ Nesses dois últimos casos, a proteção dos direitos está ligada à diligência ao transmitir a informação.

O sistema de informação pode, portanto, envolver-se ou manipular-se pelo silêncio, como se manipula por revelações falsas ou por meias-verdades: será o caso quando uma pessoa física (ou grupo despersonalizado de pessoas físicas) agir como uma pessoa jurídica, ${ }^{91}$ quando uma pessoa der a crer que esses bens estariam sob o poder de um administrador, ${ }^{92}$ que ela é representada por um mandatário ${ }^{9.3}$ ou ainda que ela é um sócio ${ }^{94}$ embora esse não seja o caso: o terceiro assim induzido a erro conservará, na medida de sua boa-fé, a dizer, sua ignorância real, o benefício da relação jurídica e terá a vantagem de um credor claramente identificado pelo regime evitado.

A falta de divulgação, como os defeitos do sistema de informação jurídica, permite freqüentemente à boa-fé governar a tealidade jurídica consagrando as aparências.

\footnotetext{
${ }^{85}$ Art. 2189 C.c.Q.

36 Art. 2195 C.c.Q.

${ }^{\text {B7 }}$ Art. 2197 C.c.Q.

${ }^{88}$ Art. 2188 C.c.Q.

8.) Art. 2452 C.c.Q.

${ }^{*}$ Art. 2497 C.c.Q.

"Art. 318 C.c.Q.

${ }^{22}$ Art. 1323 C.c.Q.

${ }^{23}$ Art. 2163 C.c.Q.

${ }^{94}$ Art. 2222 C.c.Q.
} 


\section{B - A boa-fé nos sistemas de representação e oṣ regimes de auto-correção ou remédios:}

Compreender-se-á que os sistemas de informação juridica não são perfeitos, a realidade jurídica não é sempre de fácll acesso e que o sistema falha para restabelecer o equilibrio em favor das vítimas de tais falhas. Posto que o sistema permite distorções, distorções entre a satisfação e o exercício aos direitos, entre os últimos e os poderes dos quais são acompanhados.

Esses poderes podem ser delegados ${ }^{95}$ ou partilhados ${ }^{96}$. A pluxalidade, suportada e organizada pelo direito-satisfação coletiva e exercício coletivo ou simples , separação entre satisfação e exercício - pode proteger: impor aos terceiros o estrito dever de se resignar, de suportar o peso de um etro eventual sobre uma organização interna a qual tem-se um acesso limitado, teria um efeito nocivo sobte a circulação juridica. O sistema deve compor-se com o estado de tensão o qual engendra, entra em jogo a fluidez das relações jurídicas e a segurança de suas instituições.

A proteção do terceito de boa-fé, do terceito que igno:a, é prudência, divulgação dos poderes e direitos.

Em matéria de familia: na falta de divulgação expressa, o mandato se presume pelo exercício conjunto da tutela ${ }^{97}$, da autoridade parental ${ }^{98}$ e da direção moral e material da familia ${ }^{9 \%}$. Em matérias matrimoniais, o terceiro de boa-fé aproveitará a manutenção dos contratos concluídos à título oneroso sobre os bens móveis com um dos cônjuges, embora as restrições impostas pelo regime matrimonial ${ }^{100}$ ou pelas regras relacionadas à residência familiar. ${ }^{101}$ A organização interna das sociedades é, quando ela não o é expressamente revelada, inoponivel aos terceiros de boa-fé, ${ }^{102}$ en conrrapartida, cada associado ${ }^{193}$ ou comanditado ${ }^{104}$ é mandatário da sociedade do seu ponto de vista. A boa-fé, a ignorância da dissolução das sociedades ou o prazo de administração do bem de outrem, permite a sobrevivência dos efeitos do

\footnotetext{
${ }^{95}$ Por exemplo, no caso de incapacidade de exercicio, a lei impôe a representação: art 4-153-154 C.c.Q; a representação pode igualmente ser voluntária, como no mandato.(art. 2130 C.c. Q)

* Por exemplo, para aquilo que diz respeito à residência familiar (art.401 e s. C.c.Q) ou a copropriedade( art. 1026 C.c. Q)

${ }^{97}$ Art. 194 C.c.Q.

${ }^{3}$ Art. 603 C.c.Q.

19 Art. 398 C.c.Q.

$1 \% 7$ Art. 447 C.c.Q.

$10:$ Art, 402 C.c.Q.

102 Sociedaces em nome coletivo: art. 2219 C. c. Q.; sociedades en comandita: art.2238 C.c.Q

103 Art. 2219 C.c.Q.

to4 Art, 2249 C.c.Q.
} 
regime para a melhor proteção aos terceitos, ${ }^{105}$ mas igualmente dos associados ${ }^{196} \mathrm{e}$ do administrador ${ }^{107}$.

O Direito tem a face voltada às incapacidades de seu sistema de informação, conferindo vantagens às vítimas de erros, negando ou recusando sua própria realidade ao proveito das aparêricias, no fim evidente de assegurar a estabilidade de suas instituições. Essas inflexibilidades residem no âmbito da boa-fé.

Pode-se freqüientemente unir o direito à ordem numa relação finalística: segurança, previsibilidade, justiça. Ocorre que, no entanto, o sistema jurídico engendra, pela aplicação de suas regras e princípios sua própria desordem. Direito "sagrado" entre todos, o direito de propriedade abarca todos os poderes, todas as prerrogativas de usa1, fruir e dispor livremente e completamente de um bem ${ }^{108}$. Tal princípio não deveria ceder senão para servir à utilidade pública, referência da expropriação/ desapropriação ${ }^{109}$, a proteção que a lei concede de se opor a qualquer apropriação ${ }^{110}$ feita por um vizinho de boa-fé, ${ }^{11 i}$ o Direito se consubstancia então na missão primeita de conservação de valores em detrimento de suas escolhas iniciais de política econômica. Percebe-se um movimento de ida e volta do princípio em direção ao seu ponto de meio e desse novamente até o princípio, movimento comandado pela boafé como ignorância. Esse movimento se observa facilmente em matéria sucessória: o herdeiro que aceitou expressamente ou tacitamente a sucessão ${ }^{112}$ não é aderido aos débitos senão à concortência do ativo ${ }^{113}$ salvo se ele renuncia à aplicação de regras prescritas para a liquidação ${ }^{114}$, cujo inventário ${ }^{115}$ ao qual ele será aderido aos débitos da sucessão sobre seus bens pessoais mas, nos dispõe o att 835 C.c.Q: se ele é de boa-fé e, desde que promane de fatos novos, débitos surpresa, ele pode obter do tribunal uma ordem de efeito contrário.

Os regimes jurídicos se abrem a certas condições e na falta se fecham novamente, mas se reabrem a despeito de suas próprias condições por problema de equidade, na órbita da boawé. Todos os efeitos do casamento serão acordados aos

${ }^{905}$ Administrador do bem de outrem: art. 1362 C.c. Q; sociedade em nome coletivo e em comandita: art 2234 e 2249 C.c.Q; sociedade com quotas de participação: art. 2263 C.c.Q.

tor Sociedade em nome coletivo e en comandita: art. 2233 e 2249 C.c.Q; sociedades com quotas de participação: art.2263.C.c.Q

:07 Art. 1362 C.c.Q.

108 Art. 947 C.c.Q.

${ }_{109}$ Art. 952 C.c.Q.

10 Art. 953 C.c.Q.

11 Art. 992 C.c.Q.

${ }^{112}$ Art 637 C.c.?

113 Art. 625 C.c.Q.

${ }^{114}$ Art. 779 C.c.Q.

${ }^{115}$ Art. 794 e segs. C.c.Q. 
cônjuges que ignoravam as causas de nulidade ${ }^{116}$ impede-se o efeito tetroativo de anulação por observância da boa-fé. $O$ direito reconhece a seus sujeitos a liberdade de se obrigarem voluntariamente, velando de seu lado a garantir a execução pela coação legal. O sistema guarda, no entanto um olhar crítico sobre cada etapa a qual deve ser seguida, seguida pela boa-fé como confirma agora o artigo 1375 C.c.Q. Ele comandará um retorno no tempo, apagando uma situação jurídica a qual já produziu efeitos: anulação de um ato jurídico por falta na formação ou resolução de um contrato por falta na execução, repetição do pagamento feito indevidamente, perda fortuita do objeto da prestação ${ }^{117}$. A retroatividade impõe a restituição das prestações in natura ou, em caso de impossibilidade, por equivalência ${ }^{118}$. Toda equivalência supõe uma apreciação: no caso de perda total do corpo, objeto de obrigação de restituir, seu valor equivalente variará segundo a boa ou má-fé de seu devedor. ${ }^{19}$ As duas acepções do conceito são congruentes: ignorância da recepção do indevido e causa de restituição. Aqui, a aplicação dessas medidas podem por em perigo os interesses do terceiro de boa-fé. A obrigação de restituir pode trazer o bem o qual fez subseqüentemente de objeto de alienação, de administração ou de disposição: todos esses atos deveriam normalmente seguir o tipo do primeiro, pois não podemos dar mais do que temos. Injustiça da retroação corretiva pelos terceiros os quais ignorariam a situação: o direito faz a manutenção da validade de seus atos jurídicos na medida ou órbita da boa-fé, salvo pelos atos de alienação à título gratuito ${ }^{120}$. Mesmo movimento de ida e volta pela recepção do indevido: aquilo que foi pago por erro deve ser restituído ${ }^{\mathrm{i} 21}$, mas o pagamento feito ao verdadeiro credor pelo solvens, o qual não era o seu devedor, pode provocar efeitos nefastos - prescrição do recurso, destruição da prova, abandono de uma segurança- que conduziriam a um empobrecimento tão injusto que o pagamento inicial; o regime se fecha, salvo o recurso do solvens contra o verdadeiro devedor.

Nós vimos que o direito contrapõe as disjunções entre a aparência e a realidade, entre os fatos e o direito: distorção entre a posse e propriedade, por exemplo. $O$ retorno do verdadeiro proprietário, em tempo útil, permite aos direitos reatar todo seu vigor. O reconhecimento jurídico de interesses conflituais sobre o mesmo bem obriga o direito a comaltar as lacunas: para escapar do rigor das regras de acessão, para

116 Art 382 e 383 C.c.Q: liquidação dos direitos patrimoniais; art. 385 C.c.Q: direito a doações entre vivos em consideração do casamento, art 388 C.c.Q: direito a alimentos e à prestação compensatória.

117 Art. 1699 C.c.Q.

${ }^{118}$ Art, 1700 C.c.Q.

"Is Art 1701, 1703, 1704, 1705 C.c.Q Notamos que as regras particulares se aplicam em caso de perda por força maior, regras que não são tão indiferentes à boa ou má fé do devedor (Art 1701 al. 2 C.c.Q)

${ }^{1211}$ Art. 1707 C.c.Q.

${ }^{124}$ Ant. 1491 C.c.Q. 
evitat o enriquecimento sem causa, o qual será contrário à equidade (outra acepção da boa-fé), as indenizações serão vertidas ao possuidor pelo proprietárjo com mais ou menos de generosidade, segundo a boa ou má-fé do primeiro, isto é, sua ignorância da realidade jurídica ${ }^{122}$.

Aplicar o marco jurídico às aparências surge certamente de uma legítima preocupação de assegurar a estabilidade dos negócios, uma das finalidades do direito, mas participa igualmente da busca da justiça, outra finalidade do direito.

\section{Conclusão}

Esta análise do Código Civil de Québec permite-nos concluir que o conceito de boa-fé é interpelado pelo direito sempre na busca pela justiça e em sua preocupação com a moralidade.

Regra de conduta, a boa-fé impõe uma moral individual: conceito agora enunciado, conceito posto, codificado, a boa-fé estimula suas ranificações dentro de todas as relaçôes jurídicas, como ousamos dizer, como princípio geral orientador. Dever de honestidade, de lealdade, de diligência, de prudência, de cooperação, a boafé, mesmo especificamente disposta, demanda um conceito fluido, cujo uso variará relativamente ao ritmo de decisões casuísticas, singulares e contextualizadas. Não é prejudicial que seja assim, a flexibilidade é uma qualidade essencial para administrar sociedades abertas, complexas e pluralisras.

A boa-fé opera-se igualmente com força sobre as falhas internas do sistema, bloqueando os mais evidentes efeitos da entropia. A busca de uma justiça certamente mais próxima da moralidade, do que de seguridade, moralidade mais social, mais institucional do que individual. $O$ direito é responsável por sua própria construção: esta construção é certa dentro de um sistema em que a boa-fé funda uma teoria estruturada da aparência.

Na busca pela coerência, a boa-fé como ignotância não deve jamais afástar a boa-fé como norma de conduta: a coexistência obrigatória dos fins do díreito a comanda. $O$ idealismo do direito se conjuga, nós o vimos, com o pragmatismo juridico, o objetivismo com o subjetivismo: a boa-fé, convocada ora como fim, ora como meio, apóia tanto a moralidade, quanto à segurança das relaçóes. Errguer uma incompatibilidade entre esses dois valores suporia que um é a negação do outro: este procedimento retórico ${ }^{123}$ convida à escolha, à rejeição, à hierarquia, faz pouco caso da

\footnotetext{
122 A.rt. 957 à 964 C.c.Q.

${ }^{123}$ Perelman, C., Oblbrechts-Tyteca, L. Traité de l'argumentation. $5^{2}$ ed. Bruxelas: Éditions de l'Université de Bruxelles, 1988. p. 270.
} 
solidariedade intrínseca e das acomodações que um sistema dinâmico pode e deve integrar. Se um dia, risco houver no contexto jurídico de Québec, nascerá, mais por tempo provocado por esta oposição ideológica, do que por nosso conceito inclusivo de boa-fé. 